\title{
Challenges in the management of data on extractive waste-the Polish case
}

\author{
Joanna Kulczycka ${ }^{1} \cdot$ Ewa Dziobek $^{2}$ (1) $\cdot$ Anita Szmiłyk ${ }^{2}$ \\ Received: 18 February 2019 / Accepted: 19 July 2019 / Published online: 26 August 2019 \\ (C) The Author(s) 2019
}

\begin{abstract}
The study analysed the waste statistics of European Union (EU) countries with particular emphasis on waste from extractive industries. Assessment of the data available at EU level (Eurostat) and presented by individual countries showed that even with a number of EU regulations and guidance, there are no complete, consistent and integrated reports that monitor the implementation of measures and support for waste management. Based on the example of Poland, a detailed analysis of the environmental reports from each mining company (to the regional database) and a grouping of the data according to EU waste codes were conducted for the 2017 data. The results were then compared with the data provided by the Central Statistical Office. It has been shown that there is a need for the reporting to be improved in order to avoid inconsistencies and to be able to undertake a detailed assessment of the approach and activities carried out with regard to their impact on the environment and society. Based on the example of Poland, the collection of data based on the waste code at the level of each mining company can be recommended, and this should be made available to the public by individual group of wastes on one platform (e.g. Eurostat) which would be helpful for proper waste management and the creation of industrial symbiosis and a quicker transformation towards a circular economy.
\end{abstract}

Keywords Extractive waste $\cdot$ Mining $\cdot$ Waste management and classification $\cdot$ Waste statistics $\cdot$ Polish extractive waste reporting

\section{Introduction}

Proper, unified, and more transparent data about waste management has been proposed in EU documents and collected in the Member States. This is to support the policy for minimisation of the quantity of waste generated and increasing recycling and reuse of materials and products. Extractive waste is one of the largest waste streams in Poland and in the EU. From 2004 to 2016, mining and quarrying branch (exploration, prospecting, extraction and processing of ores) have

Ewa Dziobek

ewadziobek@meeri.pl

Joanna Kulczycka

kulczycka@meeri.pl

Anita Szmiłyk

anitaszmilyk@gmail.com

1 AGH University of Science and Technology, Gramatyka 10/110, 30-067 Cracow, Poland

2 The Mineral and Energy Economy Research Institute of the Polish Academy of Sciences, Wybickiego 7A, 31-261 Cracow, Poland produced about $23-30 \%$ of waste taking into account all activities defined and presented in the Statistical Classification of Economic Activities in the European Community (NACE) and households (calculated on the basis of Eurostat data: Generation of waste by economic activity; all NACE activities and households, mining and quarrying, 2016). The need for proper waste management was defined by EU in the document Roadmap to a Resource Efficient Europe (EU COM 2011) and additionally underlined over the last few years by the introduction of the concept of the circular economy by European Commission (EC), initially in 2014-Towards a circular economy: A zero waste programme for Europe (EU COM 2014), and next in 2015 Closing the loop - An EU action plan for the Circular Economy (EU COM 2015).

Regulations have been presented concerning waste management in the mining industry in EU Member States in EU Directive 2006/21/EC (European Parliament and Council of the European Union 2006) and amending Directive 2004/35/ $\mathrm{EC}$ on the management of waste from extractive industries (EWD).

In order to monitor implementation of the directive, Member States should present reports every 3 years (first reporting period 2008-2011) based on which the EC prepares 
a summary document on the management of waste from the extractive industries. The report prepared in 2016 has shown that most of the Member States have implemented the measures and the entire EWD, but detailed assessment has been not possible since some data was not complete and/or inconsistent. Furthermore, apart from EU reporting, some of the country's own statistics are available and include data covering the topic of extractive waste; however, despite being based on EU principles, they differ in scope and category.

For some countries, as in the case of Poland, very detailed data can be presented since they are linked to the environmental fee system and required reporting, but data differs depending on the source used (Eurostat, Polish Statistical Office, Polish Geological Institute etc.). To present data consistently, it has to fall into categories and a detailed description of the waste to be assigned to each type/category has to be provided.

Some proposals for classification information about mining waste management and its impact on the environment and human health have been presented in the literature in recent years. An extensive review of the literature on the circular economy the last 20 years was carried out by Ghisellini et al. (2016). The important role of raw materials from extractive waste dumps, including their impact on the local population, was presented by Dino et al. (2018) (based on two abandoned mine sites in Italy) and also by Careddu et al. (2018). Papers by Pietrzyk-Sokulska et al. (2015), Kudełko and Nitek (2011), Korban (2011) and McLellan et al. (2009) presented the impact of extractive industries on the environment and activities undertaken in order to minimise the impact, including through the rational use of resources and pro-ecological activities. The need to increase resource efficiency was underlined by Wellmer and Hagelügen (2015). The importance of industrial symbiosis within the area of waste management and the possibility of its development through the right policy was defined by Costa et al. (2010). The policy can also create awareness of environmental reporting, as it is described by Pactwa and Wozniak (2017). The Best Available Techniques (BAT) Reference Document for the Management of Waste from Extractive Industries by Garbarino et al. (2018), a comprehensive report published by EC, presented up-to-date data and information on the management of waste from extractive industries, including key figures on this topic for Europe.

The main aim of the article is to present the current principles of extractive waste reporting and data available from various sources, as well as to provide some suggestions and recommendations to improve data statistics. The data about waste was gathered both from national statistics and individual mines to identify and compare types of generated mining waste in different classifications. It is shown that there are major inconsistences between different statistical sources. The choice of issue resulted from challenges standing before the EU Member States in the area of waste management and awareness of how consistent ongoing reports are important for the implementation of the assessment of key indicators and what changes should be done in order to meet the defined goals.

\section{Materials and methods}

The study analysed the implementation of extractive waste management measures defined in EU regulations, data completeness and consistency. The design phase was identified as the stage requiring presentation of data in line with the EU measures and guidelines. The characteristics of European countries, with special emphasis on Poland, have been based on regulations and literature studies, as well as the authors' experience in the field resulting from their academic work and business background, as well as EU projects related to waste. The Polish case study has also been prepared based on data from companies operating in 16 regions after the summarising and verification of data by waste code. The final result for 2017 is presented at a national level.

\section{EU policy promoting environmental awareness and waste minimisation, together with the classification and identification of waste from extractive industry}

The EU has introduced a set of policy recommendations promoting a circular economy, resource efficiency and waste management to minimise waste generation and storage. As a result, the waste directives were revised, and some important documents were published concerning extractive waste:

- EU Directive 2006/21/EC of the European Parliament and of the Council of 15 March 2006 on the management of waste from extractive industries and amending Directive 2004/35/EC, 'covers the management of waste resulting from the prospecting, extraction, treatment and storage of mineral resources and the working of quarries, hereinafter "extractive waste" (Article 2), defining the two most crucial waste categories:

- 'hazardous waste' is as defined in Article 1(4) of Council Directive 91/689/EEC of 12 December 1991 on hazardous waste' (OJ L 377, 31.12.1991, p. 20. Directive as amended by Regulation (EC) No 166/2006),

- 'inert waste' means waste that does not undergo any significant physical, chemical or biological transformations. Inert waste will not dissolve, burn or otherwise physically or chemically react, biodegrade or adversely affect other matter with which it comes into contact in a way likely to give rise to environmental pollution or harm human health. The total leachability and pollutant content of the 
waste and the ecotoxicity of the leachate must be insignificant, and in particular not endanger the quality of surface water and/or groundwater'.

According to the Extractive Waste Directive, necessary measures should be taken by Member States 'to ensure that extractive waste is managed without endangering human health and without using processes or methods which could harm the environment, and in particular without risk to water, air, soil and fauna and flora, without causing a nuisance through noise or odours and without adversely affecting the landscape or places of special interest. Member States shall also take the necessary measures to prohibit the abandonment, dumping or uncontrolled depositing of extractive waste' (Article 4).

Every 3 years, Member States shall deliver to the EC a report on the implementation of the Directive, based on a questionnaire and additional guidance prepared by the EC together with the Member States, according to the criteria for the classification of waste facilities and Guidance on the Waste Management (Management of Waste from the Extractive Industries) Regulations 2009 (Environmental Protection Agency). The report shall be transmitted to the EC within 9 months of the end of the 3-year period covered by it. The EC shall publish a report on the implementation of this Directive within 9 months of receiving the reports from the Member States (Article 18).

- Commission Decision of 30 April 2009 completing the technical requirements for waste characterisation laid down by Directive 2006/21/EC of the European Parliament and of the Council on the management of waste from extractive industries (notified under document number C (2009) 3013).

- EU Decision 2000/532/EC establishing a list of wastes which support in waste classification and management with its amendments (i.e. Commission Decision of 18 December 2014 amending Decision
$2000 / 532 / \mathrm{EC}$ on the list of waste pursuant to Directive 2008/98/EC of the European Parliament and of the Council). The European List of Wastes (LoW) is the waste classification in the EU for administrative purposes, i.e. for permit issuance and supervision in the field of waste generation and management. This list shall be periodically reviewed and if necessary revised. The LoW defines six-digit code waste types which are structured into 20 chapters, mainly according to the source of the waste (i.e. the economic sector or process of origin). The code of wastes for extractive industry are covered in chapter 01. Wastes resulting from the exploration, mining, quarrying, physical and chemical treatment of minerals include the following:

- 0101 wastes from mineral excavation,

- 0103 wastes from physical and chemical processing of metalliferous minerals,

- 0104 wastes from physical and chemical processing of non-metalliferous minerals,

- 0105 drilling muds and other drilling wastes.

Some of them are classified as hazardous, i.e. acid generating tailings from the processing of sulphide ore (code 0103 $04 *$ ); other tailings containing dangerous substances (code 01 $0305^{*}$ ); other wastes contain dangerous substances from the physical and chemical processing of metalliferous (code 0103 07*) and non-metalliferous minerals (code $010407 *$ ), as well as drilling muds and other drilling wastes containing oil (code $010505^{*}$ ) and dangerous substances (code 0105 06*).

Whereas in the national and EU statistics, Eurostat and Member States data are based on the Regulation (EC) 2150/ 2002 on waste statistics and its amending Regulation (EU) no. $849 / 2010$, Member States are obliged to report statistical data on waste generation and waste treatment according to the statistical waste nomenclature (European Waste Classification for Statistics - EWC-Stat defined in Guidance on classification of waste according to EWC-Stat categories,

Table 1 Waste from mining and quarrying in the EU and selected countries (million tons, Mt)

\begin{tabular}{|c|c|c|c|c|c|c|}
\hline \multirow[t]{2}{*}{ Country } & \multicolumn{2}{|l|}{2012} & \multicolumn{2}{|l|}{2014} & \multicolumn{2}{|l|}{2016} \\
\hline & Mt & $\%$ & Mt & $\%$ & Mt & $\%$ \\
\hline EU ( 28 countries), incl.: & 732.7 & 100.0 & 703.2 & 100.0 & 633.0 & 100.0 \\
\hline Bulgaria & 141.1 & 19.3 & 159.3 & 22.7 & 98.7 & 15.6 \\
\hline Poland & 68.0 & 9.3 & 75.7 & 10.8 & 70.7 & 11.2 \\
\hline Romania & 223.3 & 30.5 & 152.8 & 21.7 & 153.9 & 24.3 \\
\hline Finland & 52.9 & 7.2 & 62.8 & 8.9 & 93.7 & 14.8 \\
\hline Sweden & 129.5 & 17.7 & 138.9 & 19.8 & 109.7 & 17.3 \\
\hline
\end{tabular}

Source: Eurostat, Generation of waste by economic activity, available at https://ec.europa.eu/eurostat/tgm/refreshTableAction.do;jsessionid= ceiZsLlcWHoUGL1B33aUzqFIszFMZdAugboLmPWS0wNQKRIoEPUv!-1097325195?tab=table \&plugin=1\&pcode=ten00106\&language=en 
Table 2 Waste from section B (mining and quarrying) in Finland in 2015-2016 by category (million tons, Mt)

\begin{tabular}{lll}
\hline NACE Section B: Mining and quarrying & 2015 & 2016 \\
\hline 12.2, 12.3, 12.5 Other mineral wastes, non-hazardous & 75.2 & 88.9 \\
12.2, 12.3, 12.5 Other mineral wastes, hazardous & 0.3 & 0.6 \\
12.06 Soils, non-hazardous & 1.3 & 4.1 \\
Total & 76.8 & 93.6 \\
Of which hazardous & 0.3 & 0.6 \\
\hline
\end{tabular}

Source: Statistics Finland, Waste generation, available at https://www. stat.fi/til/jate/tau_en.html

Eurostat 2010). The EWC-Stat is a mainly substance-oriented aggregation of the waste types defined in the European List of Wastes (LoW). The result is a relationship between EWC-Stat and European LoW which allows for the unambiguous conversion of the waste types classified according to the List of Wastes into the EWC-Stat waste categories (Commission of the European Communities, 2010). According the guidance on the classification of waste according to the EWC-Stat categories published in 2010 by Eurostat, the Waste Statistics Regulation stipulates that the EWC-Stat has to be used for the reporting of data to Eurostat but it does not prescribe a specific classification to be used for data collection. Countries are free to use any waste classification as long as they can produce the defined formats in the required quality. Countries can even collect their data according to the List of Wastes and subsequently convert it to the required EWC-Stat categories. Data about waste from the extractive industry in national statistics mainly covers branch B. Exploration, mining, quarrying and physical and chemical treatment of minerals could be available mainly under Code 12.3. Naturally occurring minerals not only contain waste from the 01 group but are also chosen from $02,08,10,19$, and 20, and in the case of hazardous waste, there are $101109^{*}$ waste preparation mixtures before thermal processing containing dangerous substances and $191301 *$ solid wastes from soil remediation containing dangerous substances. Moreover, in group 03.22

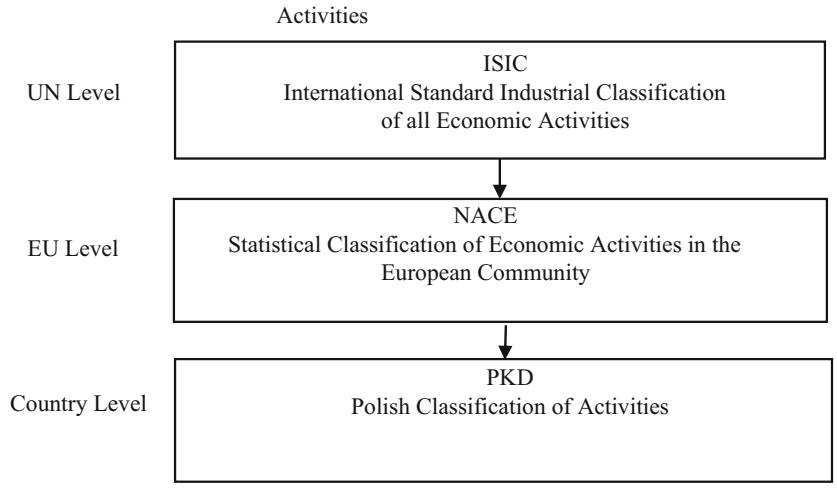

Fig. 1 Structure of the relationship between the rules for the classification of economic activities (attachment to Polish Classification of Activities, Annex to the Regulation of the Council of Ministers of 24.12.2007) sludges containing hydrocarbons, there is $010505 *$ oilcontaining drilling muds and wastes; in group 10.22, there are other mixed and undifferentiated materials, under codes 0103 99, 0104 99, and 0105 99, wastes not otherwise specified. As each Member State has its own mining and related legislation, which mainly includes legislation on the definition of mineral wastes arising as mining waste, the by-products and overburden may vary.

Unfortunately, data about generating waste in individual Member States according to the LoW are not easily available. Most publications and reports about waste from extractive industries rely on Eurostat data defined as waste from mining and quarrying, calculated at two levels-i.e. in total mass $(\mathrm{Mg})$ and in standard form as $\mathrm{kg} /$ per capita, dividing them into hazardous and non-hazardous.

Moreover, mining wastes are also defined in OECD statistics as are mining-related by-products of two types:

- mining and quarrying extraction wastes which are barren soils removed from mining and quarrying sites during the preparation for mining and quarrying and which do not enter into the dressing and beneficiating processes, and

- mining and quarrying dressing and beneficiating wastes which are obtained during the process of separating minerals from ores and other materials extracted during mining and quarrying activities.

As was underlined by Twardowska et al. (2004), due to the scarce statistical data, information on the mining waste generated and disposed of is not available for countries with the highest mining output. This sentence is still valid after almost 15 years. There are more data available, but sometimes they are not coherent.

\section{Characteristics of mining and quarrying waste in Europe-data obtained concerning the generation of mining and quarrying waste}

According to Eurostat data, the total amount of waste generated in EU countries by activity: mining and quarrying in 2016 came to 633 million tonnes (Mt), out of which 5 countries generated $83.2 \%$. The biggest contribution came from Romania with $24.3 \%$, Sweden $17.3 \%$, Bulgaria $15.6 \%$, Finland $14.8 \%$ and Poland $11.2 \%$ (Table 1).

A very small amount of the data published by individual countries is presented according to the LoW. Apart from Poland, whose detailed data is presented below, countries present data using different scopes. For example, data on mining and quarrying waste presented below is available for Finland (source: Mining and construction increased the total amount of waste in 2016, available at http://www.stat.fi/til/ 
Table 3 Mining and quarrying waste generated in Poland and waste from the extractive industry (million tons, Mt)

\begin{tabular}{|c|c|c|c|c|c|c|}
\hline Year/source & 2012 & 2013 & 2014 & 2015 & 2016 & 2017 \\
\hline OECD* & 68.0 & n.a. & 75.7 & n.a. & n.a. & n.a. \\
\hline Eurostat** & 68.0 & n.a. & 75.7 & n.a. & 70.7 & n.a. \\
\hline Poland GUS*** of which & 63.8 & 68.1 & 70.0 & 69.9 & 67.2 & 62.3 \\
\hline Sector 05 Mining of coal and lignite & 33.7 & 36.2 & 37.4 & 34.2 & 32.7 & n.a. \\
\hline Sector 07 Mining of metal ores & 28.7 & 29.0 & 29.3 & 29.8 & 30.1 & n.a. \\
\hline Sector 08 Other mining and quarrying & 1.4 & 2.9 & 3.3 & 5.6 & 4.2 & n.a. \\
\hline Sector 09 Support activities for mining and quarrying & n.a. & n.a. & 0.0 & 0.3 & 0.2 & n.a. \\
\hline
\end{tabular}

*Source: OECD, Generation of waste by sector, available at https://stats.oecd.org/Index.aspx?DataSetCode=WSECTOR; Generation of waste by sector 05-09; Mining and quarrying

**Source: Eurostat, Generation of waste by economic activity; Mining and Quarrying, available at https://ec.europa.eu/eurostat/databrowser/view/ ten00106/default/table?lang=en

***Source: Poland, Mining and quarrying Section B Polish Classification of Activities (sector 05-09) Central Statistical Office, Environment (20112018)

jate/2016/jate_2016_2018-08-31_tie_001_en.html). In Finland, mining was one of the main streams of waste in 2016, amounting to almost $76 \%$ of total waste, which totalled around $123 \mathrm{Mt}$ for the whole country (Table 2).

Despite noting the quantity and characteristics of wastes, especially from the extractive industry, has become an obligation, open access and the scope of the data are limited. The need to improve performance regarding the implementation of the EWD has been presented in the report prepared by the EC, in which gaps in implementation and their root causes have been assessed and proposals have been made to improve the implementation of the Directive.

\section{Principles of waste categorisation and reporting in Poland}

In Poland, detailed data is available concerning waste from the extractive industry, but being based on different definitions and categorisations can vary. Data on waste provided by the Central Statistical Office has been prepared based on a 'Waste catalogue' dividing wastes into groups, subgroups and types depending on the source of their generation. The system by which the main statistical relations of economic classifications link with the United Nations (UN) and EU characteristics is presented in Fig. 1.

Table 4 Waste generated from extractive industry according to the LoW in Poland in 2010 and 2017 (million tons, Mt)

\begin{tabular}{|c|c|c|c|}
\hline Waste code & Waste name & 2010 & 2017 \\
\hline Chapter 0101 & Wastes from mineral excavation & 3.2 & 7.7 \\
\hline 010101 & Wastes from metalliferous mineral excavation & 0.1 & 0.1 \\
\hline 010102 & Wastes from non-metalliferous mineral excavation & 3.0 & 7.6 \\
\hline $010180 *$ & Rock waste from copper, zinc and lead mining & 0.1 & 0.1 \\
\hline Chapter 0103 & Wastes from physical and chemical processing of metalliferous minerals & 29.6 & 29.7 \\
\hline $010381 *$ & Wastes from flotation enrichment of non-ferrous ores & 29.6 & 29.7 \\
\hline Chapter 0104 & Wastes from physical and chemical processing of non-metalliferous minerals & 29.6 & 21.5 \\
\hline 010408 & Waste gravel and crushed rocks other than those mentioned in 010407 & 0.2 & 1.0 \\
\hline 010412 & Tailings and other wastes from washing and cleaning of minerals other than those mentioned in 010407 and 010411 & 27.8 & 19.4 \\
\hline 010413 & Waste from stone cutting and sawing other than those mentioned in 010407 & 0.0 & 0.0 \\
\hline 010481 & Waste from coal flotation enrichment & 1.4 & 1.1 \\
\hline 010499 & Waste not otherwise specified & 0.0 & 0.0 \\
\hline Chapter 0105 & Drilling muds and other drilling wastes & 0.1 & 0.0 \\
\hline 010508 & Chloride-containing drilling muds and wastes other than those mentioned in 010505 and 010506 & 0.1 & 0.0 \\
\hline
\end{tabular}

Source: Polish Geological Institute, Extractive waste generation, available at http://geoportal.pgi.gov.pl/odpady/wytwarzanie/ ilosc rodzaj (2010) and own calculation based on regional reports on extractive wastes (voivodship reports in the level of companies (2017))

${ }^{1)}$ Data verified based on KGHM Integrated Report (2017) and report from Dolnośląskie voivodship (2017)

*These codes are used in Polish statistics 


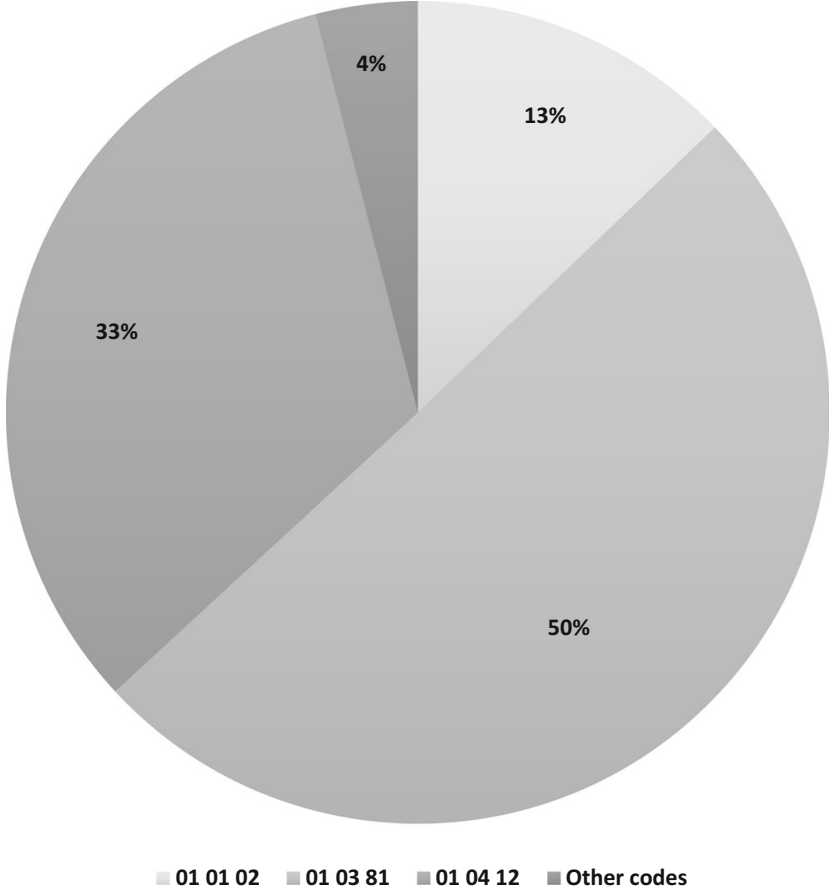

Fig. 2 Waste codes generated in the largest quantities in Poland in 2017 based on provincial reports on waste management

Even if Polish statistics are correlated with UN and EU data, some of the figures are not available and published data are not coherent for the same levels and years (see Table 3).

OECD and Eurostat data covers not only waste from mining and processing operations but also some smelting operations and they are probably higher than Polish ones according to the Polish Central Statistical Office (GUS); the total amount of mining and quarrying waste generated in 2017 in Poland was as high as 62.3 million tons (Mt), i.e. $54.7 \%$ of the total waste (excl. municipal waste). As in previous years, it was the largest source of waste in the country. Annual generation of hard coal mining waste in 2000-2016 accounted about 30-37 Mt and waste from metal ore mining, almost entirely tailings, accounted for about 30.9 Mt. Detailed sectoral data for 2017 are not available, as the format and scope of the data has changed.

According to the European Waste Catalogue and Hazardous Waste List valid from 1 January 2002, introduced by the Environmental Protection Agency, wastes resulting from exploration, mining, quarrying, physical, and chemical treatment of minerals are assigned to chapter 01 . A report based on the waste catalogue was prepared by the Polish Geological Institute for 2010. For the following years, data were not easily available but could be collected based on individual regional reports which contained data from individual mines that were delivered to the regional database (voivodships). Data which was collected and verified according to the LoW for Poland is presented in Table 4.

The waste group 01 is dominated by categories of waste produced by the mining of energy raw materials, mainly coal, and by copper ore processing. The greatest quantity of waste produced in Poland is classified under waste code $010381-$ Wastes from flotation enrichment of non-ferrous ores other than listed in 010380 . In 2010, 29.07 Mt of those wastes was produced, $54 \%$ of all mining wastes in the country.

The second biggest waste category produced in Poland is waste with code 0104 12-Tailings and other wastes from washing and cleaning of minerals other than those mentioned in 0104 07 and 0104 11, with a production of $27.82 \mathrm{Mt}$. in 2010, almost $40 \%$ of all mining wastes in the country. A significant decline in the quantity of this type of waste to $19.38 \mathrm{Mt}$ can be seen in 2017 due to the reduction in hard coal mining in Poland. Those two waste categories constituted $94 \%$ of all mining wastes.

Stricter environmental regulation in Poland underlined the need to reduce the negative impact of the mining industry on the environment and society with the result that different activities have been undertaken to reduce the amount of waste generated. The amounts of waste classified to certain categories have therefore continued to decrease until today, but the structure of the wastes remains the same (Fig. 2).

\section{Summary}

Management of waste from extractive industries is subject to regulation under EU policies, i.e. the EU Directive on Waste from Extractive Industries, which is intended to prevent or minimise any undesirable impact on the environment, the economy or human health. However, in order to manage wastes properly, the characteristics of waste must be evaluated by strategic environmental assessment and proper monitoring based on the quality and consistency of data, and reports must be produced. Only with safe operation of the mining industry, an ability to anticipate and reduce the hazards associated with waste, as well as improving safety in waste disposal and in minimising the quantity of waste produced, can the goals be achieved.

However, even with the introduction of several guidelines and documents detailing basic Directives, as well as their implementation by Member States, the reporting available is still not coherent and sufficient from the point of view of its scope. Differences in numbers from different sources can be noted. To change that, further work is needed on a more detailed description for classification purposes as well as assessment/comparison of the data reported. A modified policy framework should be devised and additional questions should be put in order to improve the quality of reporting. The EC has been working with Member States, the mining industry and experts to find the best solution for improving extractive waste management based on transparent and coherent data.

Open Access This article is distributed under the terms of the Creative Commons Attribution 4.0 International License (http:// 
creativecommons.org/licenses/by/4.0/), which permits unrestricted use, distribution, and reproduction in any medium, provided you give appropriate credit to the original author(s) and the source, provide a link to the Creative Commons license, and indicate if changes were made.

\section{References}

Careddu N, Dino GA, Danielsen SW, Přikry R (2018) Raw materials associated with extractive industry: an overview. Resour Policy 59:1-6. https://doi.org/10.1016/j.resourpol.2018.09.014

Commission Decision of 18 December 2014 amending Decision 2000/532/EC on the list of waste pursuant to Directive 2008/98/ EC of the European Parliament and of the Council (Text with EEA relevance) (2014/955/EU) (Off J EU, L 370/44, 30.12.2014)

Costa I, Massard G, Agarwal A (2010) Waste management policies for industrial symbiosis development: case studies in European countries. J Clean Prod 18:815-822. https://doi.org/10.1016/j.jclepro. 2009.12.019

Dino GA, Mehta N, Rossetti P, Franco Ajmone-Marsan F, De Luca DA (2018) Sustainable approach towards extractive waste management: two case studies from Italy. Resour Policy 59:33-43. https://doi.org/ 10.1016/j.resourpol.2018.07.009

EC (2011) Communication from the Commission to the European Parliament, the Council, the European Economic and Social Committee and the Committee of the Regions: roadmap to a resource efficient Europe, COM (2011) 0571 final

EC (2014) Communication from the Commission to the European Parliament, the Council, the European Economic and Social Committee and the Committee of the Regions: towards a circular economy: a zero waste programme for Europe. COM (2014) 0398

EC (2015) Communication from the Commission to the European Parliament, the Council, the European Economic and Social Committee and the Committee of the Regions: closing the loop-an EU action plan for the circular economy. COM (2015) 614/2

EC (European Parliament and Council) (2006) Directive 2006/21/EC of the European Parliament and of the Council of 15 March 2006 on the management of waste from extractive industries and amending Directive 2004/3 5/EC regulated the area by Directive 2006/21/EC of the European Parliament and of the Council of 15 March 2006 on the management of waste from extractive industries and amending Directive 2004/35/EC, Off J EU, L 102/15, 11.4.2006

Environment (2011-2018), Mining and quarrying Section B Polish Classification of Activities (Sector 05-09) Central Statistical Office, https://stat.gov.pl/obszary-tematyczne/srodowisko-energia/ srodowisko/ochrona-srodowiska-2018,1,19.html\#archive. Accessed 08 July 2019

Eurostat database: Generation of waste by economic activity, https://ec. europa.eu/eurostat $/ \operatorname{tgm} /$ refreshTableAction.do;jsessionid= ceiZs L1c W Ho U G L1B 33 a UzqF Is zF M Zd A u g b o L m PWS0wNQKRIoEPUv!-1097325195? tab=table\&plugin= $1 \&$ pcode $=$ ten $00106 \&$ language $=e n$. Accessed $13 \mathrm{Feb} 2019$

Eurostat (2010) Guidance on classification of waste according to EWCStat categories Supplement to the Manual for the Implementation of the Regulation (EC) No 2150/2002 on Waste Statistics, https://ec. europa.eu/eurostat/documents/342366/351806/Guidance-onEWCStat-categories-2010.pdf/0e7cd3fc-c05c-47a7-818f1c2421e55604. Accessed 13 February 2019
Garbarino E, Orveillon G, Saveyn HGM, Barthe P, Eder P (2018) EC, Best available techniques (BAT) reference document for the management of waste from extractive industries. JRC Science for Policy Report

Ghisellini P, Cialani C, Ulgiati S (2016) A review on circular economy: the expected transition to a balanced interplay of environmental and economic systems. J Clean Prod 114:11e32-11e32. https://doi.org/ 10.1016/j.jclepro.2015.09.007

KGHM Integrated Report (2017) website: kghm-raport-zintegrowany2017-en.pdf. Accessed 13 February 2019

Korban Z (2011) Problem odpadów wydobywczych i oddziaływania ich na środowisko, na przykładzie zwałowiska nr 5A/W-1 KWK ,X, Górnictwo i Geologia, Tom 6, Zeszyt 1

Kudełko J., Nitek D. (2011) Wykorzystanie odpadów z działalności górniczej jako substytutów surowców mineralnych, CUPRUM nr $3(60)$

McLellan BC, Corder GD, Giurco D, Green S (2009) Incorporating sustainable development in the design of mineral processing operations - review and analysis of current approaches. J Clean Prod 17(16): 1414-1425. https://doi.org/10.1016/j.jclepro.2009.06.003

OECD database: Generation of waste by sector, https://stats.oecd.org/ Index.aspx?DataSetCode=WSECTOR. Accessed 13 February 2019

Pactwa K, Wozniak J (2017) Environmental reporting policy of the mining industry leaders in Poland. Resour Policy 53:201-207. https:// doi.org/10.1016/j.resourpol.2017.06.008

Państwowy Instytut Geologiczny (Polish Geological Institute data), http://geoportal.pgi.gov.pl/odpady/wytwarzanie/ilosc_rodzaj. Accessed 13 February 2019

Pietrzyk-Sokulska E, Uberman R, Kulczycka J (2015) The impact of mining on the environment in Poland - myths and reality. Gospodarka Surowcami Mineralnymi - Mineral Resources Management 31(1):45-64. https://doi.org/10.1515/gospo-20150009

Polish Classification of Activities, Annex to the Regulation of the Council of Ministers of 24.12.2007, DzU 251, poz.1885

Waste catalogue, Rozporządzenie Ministra Środowiska z dnia 9 grudnia 2014 r. w sprawie katalogu odpadów, DzU, poz. 1923

Statistics Finland, Waste generation, https://www.stat.fi/til/jate/tau_en. html. Accessed 08 July 2019

Twardowska I, Stefaniak S, Szczepańska J (2004) Solid waste: assessment, monitoring and remediation in waste management series, https://www.sciencedirect.com/topics/earth-and-planetary-sciences/ mining-waste. Accessed 13 February 2019

Urząd Marszałkowski Województwa Dolnośląskiego, Raport Wojewódzki za rok 2017 (Report from Dolnośląskie Voivodship 2017 ), website: bip.umwd.dolnys lask.pl/ dokument,iddok,1081,idmp,22,r,r. Acessed 13 Feb 2019

Waste statistics (2015) Statistics Finland, https://www.stat.fi/til/jate/2015/ jate_2015_2017-06-15_en.pdf. Accessed 13 February 2019

Wellmer FW, Hagelüken C (2015) The feedback control cycle of minerals supply, increase of raw materials efficiency, and sustainable development, Minerals 5, 815-836, https://pdfs.semanticscholar.org/ 95f4/0f211a9b6a8055be37242df9f77086a58112.pdf. Accessed 13 February 2019

Publisher's note Springer Nature remains neutral with regard to jurisdictional claims in published maps and institutional affiliations. 